\title{
Serosurvey of antibodies against spotted fever group Rickettsia spp. in horse farms in Northern Paraná, Brazil
}

\author{
Soroprevalência de anticorpos contra Rickettsia spp. do grupo febre maculosa \\ em equinos de haras no Norte do Paraná, Brasil
}

Katia Tamekuni ${ }^{1}$; Roberta dos Santos Toledo ${ }^{1}$; Mauro de Freitas Silva Filho'; Valeska Bender Haydu²; Richard Campos Pacheco ${ }^{3}$; José Henrique Cavicchiolí; ; Marcelo Bahia Labruna ${ }^{5}$;

John Stephen Dumler ${ }^{6}$ O Odilon Vidotto ${ }^{7 *}$

\begin{abstract}
${ }^{1}$ Programa de Pós-Graduação em Ciência Animal, Universidade Estadual de Londrina - UEL
${ }^{2}$ Hospital Escola Veterinário, Universidade Estadual de Londrina - UEL

${ }^{3}$ Faculdade de Agronomia e Medicina Veterinária, Universidade Federal de Mato Grosso - UFMT

${ }^{4}$ Curso de Medicina Veterinária, Universidade Norte do Paraná - UNOPAR

${ }^{5}$ Departamento de Medicina Veterinária Preventiva e Saúde Animal, Universidade de São Paulo - USP

${ }^{6}$ Department of Pathology, The Johns Hopkins University School of Medicine

${ }^{7}$ Departamento de Medicina Veterinária Preventiva, Universidade Estadual de Londrina - UEL
\end{abstract}

Received April 16, 2010

Accepted September 23, 2010

\begin{abstract}
Brazilian spotted fever (BSF) is an emerging disease most likely caused by Rickettsia rickettsii. The objective of the present study was to estimate the seroprevalence of BSF rickettsia infections in equines from six horse farms located in Londrina County, Paraná, Southern Brazil. Six owners of horse farms situated in Cambé, Santa Fé, Guaraci and Londrina municipalities participated in the study. All farms were located in areas where BSF has not been reported. A total of 273 horses were sampled and their sera were tested by indirect Immunofluorescence assay (IFA) using $R$. rickettsii and $R$. parkeri antigens. Titers equal to and greater than 64 were considered positive. Of 273 sera tested, $15(5.5 \%)$ reacted to $R$. rickettsii and $5(1.8 \%)$ to $R$. parkeri. Five out of the six farms studied revealed seropositive animals and seropositivity rate ranged from 0 to $13 \%$. The titers ranged from 64 to 512 , and four samples had a titer of 512. Nine animals reacted to $R$. rickettsii with titers four-fold higher than those for $R$. parkeri. These results suggest that horses in Northern Paraná may have been exposed to rickettsiae identical or closely related to $R$. rickettsii.
\end{abstract}

Keywords: Brazilian spotted fever, Amblyomma spp., Rickettsia spp., horse farms.

\section{Resumo}

Febre Maculosa Brasileira (FMB) é uma doença emergente, sendo Rickettsia rickettsii o seu principal agente etiológico. O objetivo deste estudo foi determinar a soroprevalência de rickettsia do grupo da febre maculosa em equinos de seis haras localizados nos municípios de Cambé, Santa Fé, Guaraci e Londrina. As propriedades eram localizadas na regiāo Norte do Paraná onde casos de FMB ainda não foram diagnosticados. Foram colhidas amostras de sangue de 273 equinos, e os soros foram testados pela RIFI, usando $R$. rickettsii e $R$. parkeri como antígenos, considerando-se como positivos títulos $\geq 64$. Entre 273 soros, $15(5,5 \%)$ reagiram contra $R$. rickettsii e $5(1,8 \%)$ para $R$. parkeri. Cinco de seis haras estudados tinham animais reativos, e a taxa de sororreatividade variou de 0 a $13 \%$. Os títulos variaram de 64 para 512, e três amostras apresentaram título de 512. Nove animais reagiram para $R$. rickettsii com títulos quatro vezes maiores que para $R$. parkeri. Esses resultados sugerem que equinos no Norte do Estado do Paraná, Brasil, podem ter sido expostos a uma rickettsia idêntica ou muito próxima a $R$. rickettsii.

Palavras-chave: Febre maculosa brasileira, Amblyomma spp., Rickettsia spp., equinos.

\footnotetext{
${ }^{*}$ Corresponding author: Odilon Vidotto

Departamento de Medicina Veterinária Preventiva,

Universidade Estadual de Londrina - UEL, Campus Universitário,

CP 6001, CEP 86051-990, Londrina - PR, Brazil;

e-mail: vidotto@uel.br
} 
Brazilian spotted fever (BSF) is an acute tick-borne disease caused by $R$. rickettsii and its clinical signs include fever, headache, myalgia, nausea and rash. The first case of BSF was reported in 1929 in the State of São Paulo (DIAS; MARTINS, 1939) and in recent years BSF has been reported in the State of Minas Gerais, Rio de Janeiro, Santa Catarina, Rio Grande do Sul and Paraná (FREITAS et al., 2010).

Indirect immunofluorescence assay (IFA) is currently the test of choice for the diagnosis of rickettsioses in humans and animals. However, cross-reactivity between Rickettsia species is seen in IFA. IFA does not allow to determining the etiologic Rickettsia species, but by comparing titers among different antigens, serological similarities and presumptive etiologic agents can be inferred (LASCOLA; RAOULT, 1997; HORTA et al., 2004; PACHECO et al., 2007).

Rickettsia spp. are transmitted by ticks of Amblyomma genus, and the most important species responsible for transmitting $R$. rickettsii that causes $\mathrm{BSF}$ is $A$. cajennense, which is often identified in humans with BSF (MOREIRA; MAGALHÂES, 1935). Horses are primary hosts for all parasitic stages of $A$. cajennense, and they have been described as excellent sentinels for BSF in many studies (SANGIONI et al., 2005; HORTA et al., 2007; PINTER et al., 2008).

The objective of the present study was to obtain seroepidemiological information about spotted fever group (SFG) rickettsia infections among horses on farms located in Northern Paraná, southern Brazil, through serological testing by IFA using $R$. rickettsii and $R$. parkeri antigens.

The study was carried out on six horse farms located in Londrina County (23 $18^{\prime} 39^{\prime \prime} \mathrm{S}$ and $\left.51^{\circ} 09^{\prime} 53^{\prime \prime} \mathrm{W}\right)$, Northern Paraná, a region with no reported BSF cases. A total of 273 horse blood samples were collected and sera were separated and stored at $-20{ }^{\circ} \mathrm{C}$ before use. The number of samples collected at each farm was as follows: 50 in Cambé, 44 in Santa Fé, 25 in Guaraci, 35 in Londrina 1, 34 in Londrina 2, and 85 in Londrina 3. All of them are in a rural area, except for Londrina 1 farm that is located in an urban area. Londrina 1 farm is an equestrian school where horses are kept in stables with no access to pastures. In all other farms the animals were kept in pastures and had access to a forested area. Tick control was carried out by spraying with pyrethroids and oral ivermectin when ticks were found on the animals. The collection of animal blood was approved by the Universidade Estadual de Londrina (UEL) Ethics Committee on Animal Experiments (number 82/2006).

All horse sera were tested by IFA following Horta et al. (2004) protocol using two Rickettsia species: $R$. rickettsii strain Taiaçu (PINTER; LABRUNA, 2006) and $R$. parkeri strain São Paulo (SILVEIRA et al., 2007). Briefly, Rickettsia species were cultivated on Vero cells until $100 \%$ of cells were infected. Slides were then prepared by harvesting cells and air drying onto multiwell Teflon-coated glass slides, fixed in acetone, and stored at $-20{ }^{\circ} \mathrm{C}$ before use. The slides were examined using an epifluorescence microscope (Olympus, Japan) and titers $\geq 64$ were considered positive.

Table 1 summarizes the serological results of IFA for the six horse farms studied. Seropositive titers ranged from 64 to 512. Of 15 positive sera, 11 had $R$. rickettsii titers at least four-fold higher than $R$. parkeri titers. These sera were considered reactive to $R$. rickettsii or very closely related species (Table 2 ).

Two different tick species identified as $A$. cajennense and Anocentor nitens were detected on the horses during sampling. The study variables ciliary forest $(\mathrm{p}=0.029)$ and wild animals (capybaras / Hydrochoerus hydrochaeris and New World opossums / Didelphis spp.) ( $\mathrm{p}=0.029)$ showed significant statistical associations with $R$. rickettsii seropositivity. Only animals more than one year old were seropositive for $R$. rickettsii. There were no seropositivity differences between gender and breed of the animals. Ticks were found only on $2.9 \%$ of the horses studied.

The rate of seropositive horses found in this study is similar to that reported by Freitas et al. (2010) in São José dos Pinhais, Southern Paraná (9.33\%), and lower than those found by HORTA et al. (2007) and LEMOS et al. (1996) (19 and 27.3\%, respectively) in Southeast Brazil in BSF endemic areas. In contrast with our results, Toledo et al. (2010), while studying work horses in an urban area of Londrina, found a seroprevalence of 38.5\%. This

Table 1. Seropositivity rates by indirect immunofluorescence assay (IFA) using two different Rickettsia antigens in horses from six farms in Northern Paraná, Brazil.

\begin{tabular}{ccc}
\hline \multirow{2}{*}{$\begin{array}{c}\text { Farms } \\
\text { studied }\end{array}$} & \multicolumn{2}{c}{ IFA positive reaction/Total collected (\%) } \\
\cline { 2 - 3 } & \multicolumn{2}{c}{ Antigens } \\
\cline { 2 - 3 } & $\boldsymbol{R}$. rickettsii & $\boldsymbol{R}$. parkeri \\
\hline Cambé & $6 / 50(12)$ & $0 / 50(0)$ \\
Santa Fé & $1 / 44(2.3)$ & $0 / 44(0)$ \\
Guaraci & $1 / 25(4)$ & $0 / 25(0)$ \\
Londrina 1 & $0 / 35(0)$ & $0 / 35(0)$ \\
Londrina 2 & $4 / 34(11.8)$ & $2 / 34(5.9)$ \\
Londrina 3 & $3 / 85(3.5)$ & $3 / 85(3.5)$ \\
\hline Total & $15 / 273(5.5)$ & $5 / 273(1.8)$ \\
\hline
\end{tabular}

Table 2. Antibody titers by indirect immunofluorescence assay (IFA) using two different Rickettsia spp. antigens in horses from six farms in Northern Paraná, Brazil.

\begin{tabular}{ccccc}
\hline Sera & Area & \multicolumn{2}{c}{ IFA titers } & Probable \\
\cline { 3 - 4 } & & R. rickettsii & $\boldsymbol{R}$. parkeri & causative species \\
\hline H2 & Cambé & 518 & NR & R. rickettsii \\
H7 & Cambé & 64 & NR & R. rickettsii \\
H16 & Cambé & 518 & NR & R. rickettsii \\
H25 & Cambé & 256 & NR & R. rickettsii \\
H37 & Cambé & 256 & NR & R. rickettsii \\
H42 & Cambé & 256 & NR & R. rickettsii \\
H109 & Guaraci & 64 & NR & R. rickettsii \\
H112 & Londrina 2 & 128 & 64 & ND \\
H117 & Londrina 2 & 128 & NR & R. rickettsii \\
H138 & Londrina 2 & 512 & 256 & ND \\
H144 & Londrina 2 & 128 & NR & R. rickettsii \\
H191 & Londrina 3 & 64 & 64 & ND \\
H207 & Londrina 3 & 64 & 64 & ND \\
H226 & Londrina 3 & 256 & 64 & R. rickettsii \\
H184 & Santa Fé & 128 & NR & R. rickettsii \\
\hline
\end{tabular}

$\mathrm{NR}=$ Nonreactive. ND = Not determined. 
discrepancy could be explained by environmental and animal tick infestations, which were higher in urban Londrina than in horse farms.

Our study found only few $A$. cajennense ticks on horses and low seropositivity rate in these animals. Thus, rickettsia infection in humans transmitted by $A$. cajennense in these areas is unlikely because of very limited exposure of humans to ticks. And, in fact, there are no human BSF cases reported in this area.

Sangioni et al. (2005) recommended surveys of horse sera as useful methods for BSF surveillance in areas where humans are exposed to $A$. cajennense ticks. However, due to low seropositivity rates and under the conditions present in our study, horses cannot be used as sentinel animals because of low exposure to Amblyomma spp. ticks and consequent lower risk to humans and other animals living in these areas.

The titers against Rickettsia spp. found in this study ranged from 64 to 512 with three samples reaching 512 . Nine animals reacted to $R$. rickettsii showing titers that were four-fold higher than those seen for $R$. parkeri suggesting the circulation of Rickettsia spp. homologous to $R$. rickettsii in the population studied.

IFA is the gold standard test for rickettsioses in humans and animals (LASCOLA; RAOULT, 1997). However, cross-reactivity between Rickettsia species is common and therefore identification of Rickettsia species causing infection in BSF is difficult (HORTA et al., 2004; LABRUNA et al., 2004; PACHECO et al., 2007).

The present study provides important evidence that horses in farms in Northern Paraná may have been exposed to rickettsiae identical or closely related to $R$. rickettsii. Monitoring rickettsial infections in horses is a valuable action for preventing BSF in humans exposed to ticks. Further epidemiological studies examining other potential domestic and wild reservoirs for BSF are needed in this area and other areas in the State of Paraná.

\section{References}

DIAS, E.; MARTINS, A. V. Spotted fever in Brazil. A summary. American Journal of Tropical Medicine, v. 19, p. 103-108, 1939.

FREITAS, M. C. D. O. et al. Brazilian spotted fever in cart horses in a non-endemic area in Southern Brazil. Revista Brasileira de Parasitologia Veterinária, v. 19, n. 2, p. 130-131, 2010.
HORTA M. C. et al. Prevalence of antibodies to spotted fever group rickettsiae in humans and domestic animals in a Brazilian Spotted fever endemic area in the state of São Paulo, Brazil: serologic evidence for infection by Rickettsia rickettsii and another spotted fever group rickettsia. American Journal of Tropical Medicine and Hygiene, v. 71, n. 1, p. 93-97, 2004.

HORTA, M. C. et al. Rickettsia infection in five areas of the state of São Paulo, Brazil. Memórias do Instituto Oswaldo Cruz, v. 102, n. 7, p. 793-801, 2007.

LABRUNA, M. B. et al. Rickettsia species infecting Amblyomma cooperi ticks from an area in the state of São Paulo, Brazil, where Brazilian spotted fever is endemic. Journal Clinical of Microbiology, v. 42, n. 1, p. $90-98,2004$.

LASCOLA, B.; RAOULT, D. Laboratory diagnosis of Rickettsioses: current approaches to diagnosis of old and new Rickettsial diseases. Journal of Clinical Microbiology, v. 35, n. 11, p. 2715-2727, 1997.

LEMOS, E. R. S. et al. Epidemiological aspects of the Brazilian Spotted Fever: Serological survey of dogs and horses in an endemic area in the state of São Paulo, Brazil. Revista do Instituto de Medicina Tropical de Sáo Paulo, v. 38, n. 6, p. 427-430, 1996.

MOREIRA, J. A.; MAGALHĀES, O. Thypho exanthematico em Minas Gerais. Brasil Médico, v. 44, p. 465-470, 1935.

PACHECO, R. C. et al. Rickettsial infection in capybaras (Hydrochoerus hydrochaeris) from São Paulo, Brazil: serological evidence for infection by Rickettsia bellii and Rickettsia parkeri. Biomédica, v. 27, n. 3, p. 364-371, 2007.

PINTER, A. et al. Serosurvey of Rickettssia spp. in dogs and humans from an endemic area for Brazilian spotted fever in the state of São Paulo, Brazil. Caderno de Saúde Pública, v. 24, n. 2, p. 247-252, 2008.

PINTER, A.; LABRUNA, M. B. Isolation of Rickettsia rickettsii and Rickettsia bellii in cell culture from the tick Amblyomma aureolatum in Brazil. Annals of New York Academy of Sciences, v. 1078, n. 1, p. 523-529, 2006.

SANGIONI, L. A. et al. Rickettsial Infection in Animals and Brazilian Spotted Fever Endemicity. Emerging Infectious Diseases, v. 11, n. 2, p. 265-270, 2005.

SILVEIRA, I. et al. Rickettsia parkeri in Brazil. Emerging Infectious Diseases, v. 13, n. 7, p. 1111-1113, 2007.

TOLEDO, R. S. et al. Infection by Spotted Fever Rickettsiae in people, dogs, horses and ticks in Londrina, Parana State, Brazil. Zoonosis and Public Health, 2010. in press. 